\title{
Status Asetilator Gen NAT2 pada Pasien Tuberkulosis dan Tuberkulosis dengan Diabetes Melitus di Kupang, Nusa Tenggara Timur
}

\author{
Alvinsyah Adhityo Pramono, ${ }^{1}$ Simeon Penggoam, ${ }^{2,3}$ Edhyana Sahiratmadja, ${ }^{4}$ Novi Vicahyani Utami, ${ }^{5}$ \\ Tri Hanggono Achmad, ${ }^{4}$ Ramdan Panigoro ${ }^{4}$ \\ ${ }^{1}$ Departemen Biokimia dan Biologi Molekuler Fakultas Kedokteran Universitas Padjadjaran Bandung, ${ }^{2}$ \\ Pascasarjana Fakultas Kedokteran Universitas Padjadjaran, ${ }^{3}$ Laboratorium Mikrobiologi, RSUD Prof WZ \\ Johannes, Kupang, NTT, ${ }^{4}$ Departemen Biokimia dan Biologi Molekuler Fakultas Kedokteran Universitas \\ Padjadjaran, ${ }^{5}$ Departemen Farmakologi dan Terapi Fakultas Kedokteran Universitas Padjadjaran, Bandung
}

\begin{abstract}
Abstrak
Indonesia adalah negara dengan jumlah penderita tuberkulosis (TB) terbanyak kedua di dunia. Diabetes melitus (DM) merupakan salah satu komorbid TB. Arylamine $N$-acetyltransferase 2 (NAT2) adalah enzim yang berfungsi memetabolisir isoniazid (INH) yang disandi oleh gen NAT2. Gen NAT2 memiliki sejumlah polimorfisme dan dapat menentukan kemampuan seseorang untuk memetabolisir obat yang disebut status asetilator. Pada individu dengan status asetilator lambat, INH dimetabolisir dengan lambat sehingga memungkinkan terjadi intoksikasi hati. Pada TB dengan DM (TBDM) status asetilator lambat dapat membuat pengobatan TB maupun DM menjadi kurang optimal. Penelitian ini bertujuan mengeksplorasi status asetilator pasien TBDM di RSUD Prof. WZ Johannes Kupang periode Juni-November 2011. Pada penelitian potong lintang ini DNA dari darah 122 pasien TB diisolasi dan gen NAT2 kemudian diamplifikasi dan disekuensing untuk diketahui status asetilatornya. Hasil penelitian menunjukkan terdapat 5 pasien yang memiliki glukosa serum $>200 \mathrm{mg} / \mathrm{dL}$ yang dikategorikan sebagai pasien TBDM. Pada pasien TBDM didapatkan seorang dengan status asetilator cepat (NAT2*4/NAT2*4), 2 orang dengan status asetilator sedang (NAT2*13A/NAT2*6J), dan 2 orang dengan status asetilator lambat (NAT2*5/NAT2*5G, NAT2*6A/ NAT2*6A, NAT2*7B/ NAT2*7B). Pada pasien TB yang dipilih secara random berdasar usia dan jenis kelamin serupa dengan TBDM didapatkan 2 orang dengan status asetilator cepat (NAT2*4/NAT2*4) dan 3 orang dengan asetilator sedang (NAT2*4/NAT2*6A, NAT2*13A/NAT2*6J). TBDM yang memiliki status asetilator lambat berpotensi memiliki masalah ganda dalam terapi, selain dapat terjadi toksisitas hati akibat terapi dengan INH, juga dapat mengakibatkan pengobatan DM menjadi tidak optimal. Perlu dilakukan peneltian lebih lanjut terkait farmakogenetik pada TBDM. [MKB. 2017;49(1):61-6]
\end{abstract}

Kata kunci: Asetilator, isoniazid, NAT2, farmakogenetik, tuberkulosis

\section{NAT2 Gene Acetylator Status of Tuberculosis and Tuberculosis with Diabetes Mellitus Patients in Kupang, Nusa Tenggara Timur}

\begin{abstract}
Indonesia is the second highest country with TB patients in the world. Diabetes mellitus (DM) is a comorbid of TB. Arylamine N-acetyltransferase 2 (NAT2), encoded by the NAT2 gene, is an enzyme that metabolizes isoniazid (INH). NAT2 gene has some polimorphysims that may play a role in INH acetylating process. Those who are slow acetylators may develop liver intoxication as a consequence of slow INH metabolism process. Slow acetylator TBDM patients may complicate both TB and DM treatment, causing them to be less optimal. The aim of this study was to explore the acetylator status of TBDM patients in Kupang, Indonesia. A cross-sectional study was conducted by obtaining DNA of 122 TB patients in Kupang in June-November 2011. NAT2 gene was amplified and sequenced to determine the acetylator status. There were 5 TB patients who had a glucose serum level of $>200 \mathrm{mg} / \mathrm{dL}$ and was catagorized as TBDM. Result showed that there was 1 TBDM patient who was a rapid acetylator (NAT2*4/ NAT2*4), 2 patients as intermediate acetylators (NAT2*13A/NAT2*6J), and 2 patients as slow acetylators (NAT2*5/NAT2*5G, NAT2*6A/ NAT2*6A, NAT2*7B/ NAT2*7B). Meanwhile, there were 2 TB patients who was rapid acetylators (NAT2 $* 4 / \mathrm{NAT} 2 * 4$ ) and 3 patients as intermediate acetylators (NAT2*4/NAT2*6A, NAT2*13A/ NAT2*6J). Slow NAT2 acetylator TBDM patients potentially face more problems during therapy. As INH may cause liver intoxication, these patients may also experience unoptimum DM treatment. Therefore, it is strongly recommended to do a study on the role of pharmacogenomics in TBDM. [MKB. 2017;49(1):61-6]
\end{abstract}

Key words: Acetylator, isoniazid, NAT2, pharmacogenetics, tuberculosis

Korespondensi: Alvinsyah Adhityo Pramono, Departemen Biokimia dan Biologi Molekuler Fakultas Kedokteran Universitas Padjadjaran, Jalan Raya Bandung Sumedang Km. 21, Jatinangor, mobile: 0818842041, e-mail: alvinpramono@gmail.com 


\section{Pendahuluan}

Arylamine $N$-acetyltransferase 2 (NAT2) adalah enzim yang berfungsi untuk memetabolisir obat antituberkulosis isoniazid (INH). Enzim ini disandi oleh gen NAT2 yang tidak berintron sepanjang 870 pasang basa nitrogen, yang terletak pada kromosom 8. ${ }^{1,2}$ Pada gen NAT2 ini dapat terjadi beberapa variasi sekuens DNA yang dikenal sebagai single nucleotide polymorphisms (SNPs) yang sudah menghasilkan perubahan genotip, haplotip, dan fenotip. Berdasar atas kemampuannya pada metabolisme INH, fenotip dari beberapa variasi haplotip gen NAT2 dapat dikelompokkan yaitu menjadi asetilator cepat, sedang, dan lambat. Setidaknya dibutuhkan satu sampai empat SNPs untuk mengidentifikasi genotip NAT2 yang dapat memengaruhi fenotip asetilator tersebut. ${ }^{1,2}$

Distribusi global NAT2 telah menunjukkan bahwa $15-40 \%$ penduduk dunia diketahui memiliki haplotip NAT2*6A (282C $>$ T, 590G $>A$ ), NAT2*6B (590G $>A)$ NAT2*6C (282C $>$ T, $590 \mathrm{G}>\mathrm{A}, 803 \mathrm{~A}>\mathrm{G}$ ),yang adalah fenotip asetilator lambat, dan bahkan sekitar $50-60 \%$ populasi Kaukasian merupakan asetilator lambat. ${ }^{3}$ Selain itu, dinyatakan pula bahwa $50 \%$ populasi Asia Timur, termasuk Jepang, Korea, dan Tiongkok merupakan asetilator cepat dengan haplotip NAT2*4. Haplotip ini sangat jarang ditemukan pada populasi Eropa dan Sub Sahara. ${ }^{3}$ Apabila hal ini ditilik lebih lanjut pada regio Asia Tenggara, dapat ditemukan bahwa mayoritas dari bangsa Thailand adalah asetilator cepat, dan penduduk Indonesia bagian barat yang mayoritasnya adalah orang Sunda, Jawa, dan Betawi lebih banyak membawa sifat asetilator lambat bila dibanding dengan asetilator cepat. ${ }^{4}$ Meneliti keberagaman NAT2 di Indonesia akan menjadi daya tarik tersendiri sebab negara ini didiami oleh ribuan suku bangsa dari ujung barat sampai ke ujung paling timur.

Diabetes melitus (DM) merupakan penyakit komorbid dari TB. Di Indonesia terdapat 35\% pasien DM yang menderita $\mathrm{TB}^{5}$ Selain itu, ditemukan pula bahwa individu pembawa genotip NAT2 asetilator yang lambat seperti NAT2*5A, NAT2*6A, dan NAT2*14A memiliki risiko lebih tinggi untuk menderita DM.6,8 Pasien DM asetilator lambat yang terinfeksi kuman Mycobacterium tuberculosis memiliki risiko menderita drug induced hepatitis sebagai efek samping metabolisme INH yang lebih lambat. 5,6

Dalam penelitian sebelumnya, sekuensing NAT2 pada populasi yang belum terpetakan sangat direkomendasikan. ${ }^{3}$ Keadaan yang sama berlaku pula untuk NAT2 di Kupang karena di kota ini tinggal salah satu ras yang menyimpan keragaman genetik Indonesia bagian timur yang berbeda dari wilayah barat. Berdasar atas Riskesdas 2013, prevalensi penyakit TB di Provinsi Nusa Tenggara Timur (NTT) masih di atas 30\%.7 Oleh sebab itu, penanganan kasus TB di NTT, khususnya Kota Kupang layak mendapat perhatian. $^{7}$

Penelitian ini dilakukan untuk mengeksporasi status asetilator dengan melihat profil sekuens gen NAT2 pada pasien TB dan TBDM di Kupang, Nusa Tenggara Timur.

\section{Metode}

Penelitian ini memakai desain potong lintang retrospektif mempergunakan DNA tersimpan untuk diamplifikasi gen NAT2 dan kemudian ditentukan status asetilatornya. Penelitian ini merupakan bagian dari payung penelitian yang bertujuan melihat gen-gen yang berperan pada kerentanan terhadap TB di Kupang dengan subjek penelitian adalah pasien TB paru baru yang diinklusi pada bulan Juni-November 2011 dari RSUD Prof W. Z. Johannes, Kupang. DNA dari darah pasien TB paru disimpan sesuai dengan protokol yang telah disetujui oleh Komite Etik Fakultas Kedokteran Universitas Padjadjaran Nomor 591/UN6.C2.1.2/KEPK/PN/2014.

Secara ringkas, pasien terdiagnosis TB berdasar atas manifestasi klinis, rontgen toraks, dan pemeriksaan basil tahan asam sputum. Seluruh pasien diobati menggunakan obat antituberkulosis berdasar atas panduan Kementrian Kesehatan Republik Indonesia. Pasien dengan hasil tes HIV positif tidak diikutsertakan dalam penelitian. Pasien TB dengan glukosa serum sewaktu lebih dari $200 \mathrm{mg} / \mathrm{dL}$ dimasukkan dalam kategori tuberkulosis dengan diabetes melitus (TBDM). Penelitian ini membandingkan status asetilator pasien TBDM dengan pasien TB yang dicocokkan berdasar atas usia dan jenis kelamin. Sebelum menjalani penelitian, pasien sudah menandatangani lembar persetujuannya sebagai subjek penelitian.

Sampel DNA pasien didapatkan melalui darah vena, disimpan dalam tabung EDTA pada suhu $4^{\circ} \mathrm{C}$ selama beberapa hari, lalu dipindahkan ke dalam kotak penahan dingin selama pengiriman dari Kupang ke Bandung. Isolasi DNA dilakukan berdasar atas protokol produsen (QIAamp DNA Blood Mini Kit, Cat no. 51104, Qiagen). DNA yang sudah diisolasi diamplifikasi gen NAT2 dengan menggunakan primer forward 5' - GGG ATC ATG 
GAC ATT GAA GC - 3' dan primer reverse 5' GGG TGA TAC ATA CAC AAG GGT TTA - 3'. Satu sampel PCR berisi $50 \mu \mathrm{L}$ larutan yang terdiri atas campuran $25 \mu \mathrm{L}$ larutan Master Mix (Kappa 2G Fast, Kapabiosystems), $19 \mu \mathrm{L}$ air deiodinasi, $2 \mu \mathrm{L}$ primer forward, $2 \mu \mathrm{L}$ primer reverse, dan $2 \mu \mathrm{L}$ DNA pasien. Proses PCR secara berurutan adalah denaturasi awal $\left(94^{\circ} \mathrm{C}, 3 \mathrm{~min}\right)$; denaturasi $\left(94^{\circ} \mathrm{C}\right.$, 30 detik per siklus); annealing $\left(55^{\circ} \mathrm{C}, 30\right.$ detik per siklus); ekstensi $\left(72^{\circ} \mathrm{C}\right.$, menit per siklus), dan ekstensi akhir $\left(72^{\circ} \mathrm{C}, 5\right.$ menit). Fase denaturasi, annealing, dan ekstensi masing-masing diulang sebanyak 30 siklus. Produk PCR kemudian divisualisasikan pada gel agarosa 1\% dengan daya 90V selama 20 menit. Hasil amplifikasi gen NAT2 kemudian dilakukan sekuensing (Firstbase, Singapore).

Hasil sekuensing dianalisis dengan BioEdit Sequence Alignment Editor. Identifikasi genotip NAT2 dilakukan dengan melihat 37 SNPs NAT2 sesuai dengan panduan dari The Arylamine $\mathrm{N}$-acetyltransferase Gene Nomenclature Committee (http://nat.mbg.duth.gr/Human\%20 NAT2\%20alleles_2013.htm), yang diakses pada November 2014. ${ }^{9}$ Identifikasi SNP homozigot maupun heterozigot dilakukan dengan cara memanfaatkan fitur kromatogram.

Alel NAT $2 * 4$ merupakan wild type, yaitu alel yang tidak mengalami mutasi. ${ }^{10}$ Apabila kedua alel NAT2 merupakan alel cepat (NAT2*4, NAT2*12, dan NAT2*13) maka pasien dikategorikan sebagai asetilator cepat. Apabila kedua alelnya merupakan alel selain yang disebutkan di atas maka pasien dikategorikan sebagai asetilator lambat. Apabila kedua alel merupakan kombinasi alel cepat dan lambat maka pasien dikategorikan sebagai asetilator sedang.

Uji statistika Kolmogorov Smirnov digunakan untuk melihat perbedaan antara kelompok pasien TB dan TBDM dalam hal usia dan kadar gizi $\left(\right.$ IBM $^{\circledR}$ SPSS Statistics 20). Data usia dan indeks massa tubuh (IMT) ditampilkan dalam bentuk rerata dan standar deviasi, sedangkan pada genotip NAT2 data dipaparkan diantara kedua kelompok TB dan TBDM.

\section{Hasil}

Pada periode Juni-November 2011 telah datang di RSUD Prof W. Z. Johannes, Kupang sebanyak 124 pasien TB baru dan $2(1,6 \%)$ pasien tidak diikutsertakan dalam penelitian karena hasil tes HIV menunjukkan HIV positif. Dari 122 pasien TB baru, terdapat 5 pasien $(4,1 \%)$ TB dengan glukosa sewaktu $>200 \mathrm{mg} / \mathrm{mL}$, dan dimasukkan dalam katagori TBDM. Gambaran karakteristik pasien TB dan TBDM ditampilkan dalam Tabel 1. Terdapat perbedaan usia rata-rata yang bermakna antara pasien TB dan TBDM, yaitu $35,7( \pm 13,8)$ tahun dan 54,5 $( \pm 12,8)$ tahun dengan nilai $p=0,038$ (uji Kolmogorov-Smirnov). Indeks massa tubuh (IMT) rata-rata pada TB dan TBDM tidak berbeda bermakna yaitu 15,4 $( \pm 2,35) \mathrm{kg} / \mathrm{m}^{2}$ dan $15,2( \pm 3,23) \mathrm{kg} / \mathrm{m}^{2}$ dengan nilai $\mathrm{p}=0,071$ (uji Kolmogorov-Smirnov). Data IMT hanya didapat dari 85 pasien. Dari hasil IMT didapatkan bahwa hampir seluruh pasien TB dan TBDM mengalami kurang gizi. Lebih lanjut, dapat dilihat bahwa pasien TB yang memiliki IMT normal $\left(18,5-24,9 \mathrm{~kg} / \mathrm{m}^{2}\right)$ sebanyak 11 orang $(13 \%)$ dan IMT kurang $\left(<18,50 \mathrm{~kg} / \mathrm{m}^{2}\right)$ sebanyak 70 orang $(82 \%)$, sedangkan seluruh pasien TBDM memiliki IMT kurang.

Status asetilator seluruh pasien TBDM kemudian apabila dibandingkan dengan pasien TB yang dipasangkan secara acak dengan jenis

Tabel 1 Distribusi Demografis Pasien TB dan TBDM di Kupang, Nusa Tenggara Timur

\begin{tabular}{lccc}
\hline & $\begin{array}{c}\text { Pasien TB } \\
(\mathbf{n}=\mathbf{1 1 7})\end{array}$ & $\begin{array}{c}\text { Pasien TBDM } \\
(\mathbf{n}=\mathbf{5})\end{array}$ & Nilai p \\
\hline Jenis kelamin & & - & - \\
Pria, n (\%) & $59(50,4 \%)$ & $5(100 \%)$ & - \\
Wanita, n (\%) & $58(49,6 \%)$ & $54,5( \pm 12,8)$ & 0,038 \\
Usia, tahun (rata-rata \pm SD) & $35,7( \pm 13,8)$ & $15,2( \pm 3,23)$ & 0,071 \\
IMT (rata-rata \pm SD) & $15,4( \pm 2,35)$ & - & - \\
IMT normal, n (\%) & $11(13 \%)$ & $4(100 \%)$ & - \\
IMT kurang, n (\%) & $70(82 \%)$ & - \\
\hline Keterangan: TB - tuberkulosis, TBDM - tuberkulosis dengan diabetes melitus, IMT - indeks massa tubuh, SD - standar
\end{tabular}


Tabel 2 Frekuensi Alel Pasien TB dan TBDM di Kupang, Nusa Tenggara Timur

\begin{tabular}{|c|c|c|c|c|c|}
\hline \multirow[t]{2}{*}{$\begin{array}{c}\text { Alel } \\
\text { NAT2 }\end{array}$} & $\begin{array}{c}\text { Pasien } \\
\text { TB } \\
(\mathrm{n}=5) \\
\end{array}$ & $\begin{array}{l}\text { Pasien } \\
\text { TB DM } \\
(\mathrm{n}=5) \\
\end{array}$ & \multirow[t]{2}{*}{ SNPs } & \multirow[t]{2}{*}{ Perubahan Asam Amino } & \multirow[t]{2}{*}{$\begin{array}{r}\text { Aktivitas } \\
\text { Enzimatik }\end{array}$} \\
\hline & $n$ & $n$ & & & \\
\hline$* 4$ & 5 & 3 & Wild type & - & Cepat \\
\hline$* 13 \mathrm{~A}$ & 2 & 1 & $282 \mathrm{C}>\mathrm{T}$ & Y94Y & Cepat \\
\hline$* 5 \mathrm{G}$ & - & 1 & $\begin{array}{l}282 \mathrm{C}>\mathrm{T}, 341 \mathrm{~T}>\mathrm{C}, \\
481 \mathrm{C}>\mathrm{T}, 803 \mathrm{~A}>\mathrm{G}\end{array}$ & $\begin{array}{l}\text { Y94Y, } \\
\text { I114T, } \\
\text { L161L, } \\
\text { K268R }\end{array}$ & Lambat \\
\hline$* 6 \mathrm{~A}$ & 1 & 2 & $282 \mathrm{C}>\mathrm{T}, 590 \mathrm{G}>\mathrm{A}$ & $\begin{array}{l}\text { Y94Y, } \\
\text { R197Q }\end{array}$ & Lambat \\
\hline *6J & 2 & 1 & $\begin{array}{c}282 \mathrm{C}>\mathrm{T}, 590 \mathrm{G}>\mathrm{A}, \\
857 \mathrm{G}>\mathrm{A}\end{array}$ & $\begin{array}{l}\text { Y94Y, } \\
\text { R197Q, } \\
\text { G286E }\end{array}$ & Lambat \\
\hline *7B & - & 2 & $282 \mathrm{C}>\mathrm{T}, 857 \mathrm{G}>\mathrm{A}$ & $\begin{array}{l}\text { Y94Y, } \\
\text { G286E }\end{array}$ & Lambat \\
\hline
\end{tabular}

Keterangan: TB: tuberkulosis, TBDM: tuberkulosis dengan diabetes mellitus, SNP: single nucleotide polymorphism

kelamin dan usia yang sama. Hasil sekuensing memperlihatkan bahwa alel NAT2*4 adalah alel dominan (8 dari 20 alel), diikuti dengan NAT2*13A, NAT2*6A, dan NAT2*6J (Tabel 2). Deskripsi frekuensi genotip dan fenotip NAT2 pada pasien TB dan TBDM ditampilkan pada Tabel 3. Hasil sekuensing menunjukkan bahwa tidak ada pasien TB yang berstatus asetilator lambat, sedangkan pada pasien TBDM status asetilator cepat, sedang, dan juga lambat terbagi secara merata. Namun demikian, karena jumlah pasien yang terbatas tidak dapat dilakukan analisis statistik.

\section{Pembahasan}

Pemetaan NAT2 di Indonesia bagian barat telah dilakukan $^{4}$ dan untuk menambah pemetaan NAT2 di Indonesia bagian timur maka kami melakukan melakukan penelitian ini dengan mengeksplorasi profil gen NAT2 dan status asetilator pada pasien TB dan TBDM dari Kupang, Nusa Tenggara Timur. Secara umum, hasil penelitian ini menunjukkan perbedaan bermakna pada usia pasien TB dan TBDM. Hal ini mengonfirmasi DM pada pasien TB di usia yang lebih tua sehingga perlu pemeriksaan gula pada pasien dengan TB berusia lebih dari

Tabel 3 Frekuensi Fenotip Asetilator berdasar atas Distribusi Trimodal dan Genotip NAT2 Pasien TB dan TBDM di Kupang, Nusa Tenggara Timur

\begin{tabular}{|c|c|c|c|}
\hline \multirow{2}{*}{ Fenotip } & \multirow{2}{*}{ Genotip } & TB $(n=5)$ & TB DM $(n=5)$ \\
\hline & & $\mathbf{n}$ & $\mathbf{n}$ \\
\hline \multirow[t]{2}{*}{ Asetilator cepat } & $* 4 / * 4$ & 2 & 1 \\
\hline & $* 4 / * 5 \mathrm{G}$ & - & 1 \\
\hline \multirow[t]{2}{*}{ Asetilator sedang } & $* 4 / * 6 \mathrm{~A}$ & 1 & - \\
\hline & $* 13 \mathrm{~A} / * 6 \mathrm{~J}$ & 2 & 1 \\
\hline \multirow{2}{*}{ Asetilator lambat } & $* 6 \mathrm{~A} /{ }^{*} 6 \mathrm{~A}$ & - & 1 \\
\hline & $* 7 \mathrm{~B} / * 7 \mathrm{~B}$ & - & 1 \\
\hline
\end{tabular}

Keterangan: TB: tuberkulosis, TBDM: tuberkulosis dengan diabetes mellitus 
35 tahun. ${ }^{5}$ TBDM biasanya memiliki IMT yang tinggi atau normal, ${ }^{5}$ keadaan ini tidak terjadi pada pasien penelitian ini. Pada umumnya masyarakat NTT memang memiliki IMT yang lebih rendah jika dibanding dengan provinsi lainnya seperti yang dilaporkan pada Riskesdas 2013 yang menempatkan NTT sebagai provinsi dengan gizi buruk tertinggi di Indonesia. ${ }^{11}$ Berdasarkan atas telaah tersebut, parameter antropometri, glukosa darah, serta profil lipid dan protein menjadi penting untuk diperiksa secara berkala. Prevalensi TBDM di Indonesia Barat sebesar 35\%, ${ }^{5}$ sedangkan pada studi ini didapatkan prevalensi TBDM di Kupang sebesar 4\%. Walaupun temuan TBDM cukup rendah di daerah ini, klinisi tetap harus peka terhadap kemungkinan DM pada keadaan mendiagnosis pasien TB. Dalam kaitannya dengan TBDM maka peneltian ini juga merekomendasikan pemeriksaan glukosa darah pada seluruh pasien TB di atas 35 tahun.

Menangani pasien TB dengan segala efek sampingnya amatlah berat mengingat $40-60 \%$ pasien DM adalah asetilator lambat. ${ }^{6-8}$ Apabila dibanding dengan profil NAT2 di Asia Tenggara dan Asia Timur maka akan didapat suatu proyeksi yang menunjukkan tren eskalasi NAT2 di regional tersebut, termasuk Indonesia. Pada penelitian lain dinyatakan bahwa mayoritas orang Indonesia bagian barat adalah asetilator lambat. ${ }^{4}$ Penduduk Indonesia Barat memiliki profil NAT2 yang mirip dengan kelompok etnis dari Asia Tenggara, khususnya Vietnam. ${ }^{15}$

Penelitian lanjutan di Kupang sangatlah dianjurkan mengingat kota ini ditinggali oleh berbagai macam ras dengan berbagai macam variasi genetik Indonesia. Tiga hipotesis yang dapat ditarik dari studi ini adalah apakah tren NAT2 di Indonesia akan menyamai NAT2 di Asia Tenggara atau terdapat SNP baru yang identik yang khas pada populasi Kupang.

SNP fungsional NAT2 menjadi hal menarik yang dapat membuktikan apakah perbedaan status asetilator berpengaruh terhadap kejadian kerusakan hati akibat INH. Berdasar atas konsensus NAT, alel NAT2*4 ditetapkan sebagai acuan nomenklatur NAT2 ${ }^{10}$ Pada penelitian kami ditemukan alel NAT2*5, NAT2*6, dan NAT2*7. Pada ketiga alel ini terdapat SNP fungsional yang dapat menurunkan aktivitas enzimatik NAT2. SNP fungsional pada NAT2*5G adalah $341 \mathrm{~T}>\mathrm{C}$ yang menyebabkan perubahan asam amino I114T. Lokasi asam amino I114 di perifer rantai bangunnya tidak akan menyebabkan perubahan struktur gen, stabilitas protein, dan parameter kinetik pada saat diintegrasikan ke protein struktur primer dan sekunder. Asam amino hasil mutasi I114T akan mengakibatkan perubahan residu hidrofobik menjadi hidrofobik polar, mengakibatkan degradasi protein enzimatik sehingga terjadi penurunan aktivitas enzimatik NAT2. ${ }^{13}$

SNP 590A $>$ G (R197Q) merupakan SNP fungsional yang menjadi penanda NAT2 $* 6 \cdot{ }^{13}$ Letak gugus R197 yang terdapat di permukaan protein menyebabkan gaya Van der Walls dan interaksi elektrostatis antara gugus R197, E195, dan gugus sulfur M105.11,13 Perubahan asam amino arginin menjadi glutamin menyebabkan penurunan aktivitas enzimatik NAT2 dan juga menurunkan $\mathrm{O}$-asetilasi pada senyawa $\mathrm{N}-\mathrm{OH}$ ABP dan N-OH-PhIP. ${ }^{11}$ R197Q mengganggu termostabilitas protein NAT2 dengan cara menurunkan waktu paruhnya sebanyak 3 kali lipat dan 4 kali lipat pada suhu $37^{\circ} \mathrm{C}$ dan $50^{\circ} \mathrm{C} .{ }^{11}$

Alel NAT2*7 ditandai oleh SNP fungsional $857 \mathrm{G}>\mathrm{A}$ yang terletak pada domain cabang rantai C-terminal di dekat sisi aktif molekul dan tidak berinteraksi langsung dengan residu lainnya. ${ }^{13}$ SNP ini meningkatkan besaran konstanta Michaelis Menten (Km) asetil ko-A (pada INH) dan pada saat bersamaan menurunkan $\mathrm{Km}$ untuk reaksi $\mathrm{N}$-asetilasi (pada sulfametoksazol dan dapson). Perubahan glisin menjadi glutamat mengubah sisi aktif dan selektivitas substrat sehingga ikatan asetil ko-A dan asetilasi $\mathrm{Cys}^{68}$ terganggu. Oleh sebab itu, fenotip NAT2*7 sangat bergantung pada jenis dan konsentrasi substrat. ${ }^{13}$

SNP 282C>T ditemukan pada seluruh alel mutan dan tidak menyebabkan penurunan kinematika enzim..$^{9,11}$ Penurunan aktivitas enzim disebabkan oleh SNP 341T $>$ C, 590G $>$ A, dan $857 \mathrm{G}>\mathrm{A}$ yang bertanggung jawab atas alel NAT2*5, NAT2*6, dan NAT2*7. Berdasar atas seluruh penjabaran di atas, dapat disimpulkan bahwa kemampuan asetilasi NAT2 dapat diurutkan sebagai berikut NAT2*4> NAT2*13> NAT2*7> NAT2*6> NAT2*5. ${ }^{11,14}$ Pasien TB asetilator lambat memiliki kandungan INH aktif lebih tinggi di dalam darah yang berpotensi menyebabkan hepatitis karena INH.

Selain berperan sebagai agen terapeutik, INH juga dimanfaatkan untuk profilaksis TB. Sebuah studi menunjukkan bahwa profilaksis INH sangat efektif dalam mencegah TB pada anak non-HIV usia 4 bulan sampai 15 tahun. ${ }^{11}$ Walaupun INH terbukti protektif, klinisi diharapkan dapat memonitor efek samping pada penggunaannya. Salah satu upaya yang dapat dilakukan adalah mengecek profil NAT2 dan status asetilatornya sebelum memulai profilaksis untuk mencegah 
efek hepatotoksik INH.

Kelemahan studi ini terdapat pada jumlah sampel TBDM yang didapat di antara pasien TB di Kupang, NTT. Hal ini mungkin karena memang TBDM di NTT tidak banyak dibanding dengan jumlah TBDM di Jawa Barat (35\%). ${ }^{5}$ Walaupun demikian, studi eksploratifini telah menunjukkan terdapat variasi pada pasien TBDM yang merata sehingga pemeriksaan status asetilator perlu dilakukan pada seluruh pasien TB, terlebih pada pasien TBDM sebelum memulai terapi INH.

Pada penelitian ini memberikan pandangan yang baru mengenai pemetaan NAT2 di tingkat global. Dengan pendekatan farmakogenetiknya, diharapkan setiap pasien TB yang akan diterapi INH diperiksakan status asetilatornya sebelum mendapatkan pengobatan TB untuk mencapai hasil pengobatan yang paling baik, efektif, aman, dengan efek samping paling minimal.

\section{Ucapan Terima Kasih}

Penelitian ini sebagian mendapat hibah dari Universitas Padjadjaran melalui Hibah Unggulan Fakultas Kedokteran Universitas Padjadjaran tahun 2012. Penulis mengucapkan terimakasih kepada Dr. Ani Melani Maskoen, drg., MKes., Nurul Setiarahayu, dan Dyas Tuti Utomo Aryani yang telah membantu penelitian di Laboratorium Genetika Molekuler Fakultas Kedokteran Unpad.

\section{Daftar Pustaka}

1. Sim E, Walters K, Boukouvala S. Arylamine $\mathrm{N}$-acetyltransferases: from structure to function. Drug Metab Rev. 2008;40(3):479510.

2. Sim E, Lack $N$, Wang CJ, Long $\mathrm{H}$, Westwood I, Fullam E, dkk. Arylamine N-acetyltransferases: structural and functional implications of polymorphisms. Toxicology. 2008;254(3):170-83.

3. Sabbagh A, Langaney A, Darlu P, Gérard N, Krishnamoorthy R, Poloni ES. Worldwide distribution of NAT2 diversity: implications for NAT2 evolutionary history. BMC Genet. 2008;9(1):21.

4. Yuliwulandari R, Sachrowardi Q Nishida N, Takasu M, Batubara L, Susmiarsih TP, dkk. Polymorphisms of promoter and coding regions of the arylamine $\mathrm{N}$-acetyltransferase 2 (NAT2) gene in the Indonesian population: proposal for a new nomenclature. J Hum Genet. 2008;53(3):201-9.
5. Alisjahbana B, van Crevel R, Sahiratmadja E, den Heijer M, Maya A, Istriana E, dkk. Diabetes mellitus is strongly associated with tuberculosis in Indonesia. Int J Tuberc Lung Dis. 2006;10(6):696-700.

6. Yalin S, Hatungil R, Tamer L, Ates NA, Dogruer $\mathrm{N}$, Yildirim $\mathrm{H}, \mathrm{dkk}$. N-acetyltransferase 2 polymorphism in patients with diabetes mellitus. Cell Biochem Funct. 2007;25(4):407-11.

7. Kementerian Kesehatan RI. Riset Kesehatan Dasar RISKESDAS 2013. Jakarta: Kementerian Kesehatan RI; 2013.

8. Irshaid YM, Abujbara MA, Ajlouni KM, ElKhateeb M, Jarrar YB. N-acetyltransferase-2 genotypes among Jordanian patients with diabetes mellitus. Int J Clin Pharmacol Ther. 2013;51(7):593-9.

9. Boukouvala S, Hein DW, Grant DM, Sim E, Minchin RF, Agúndez JAG, dkk. Human NAT2 Alleles (Haplotypes) 2013 [diunduh 20 Oktober 2014]. Tersedia dari: http://nat. mbg.duth.gr/. Web.

10. Hein DW, Boukouvala S, Grant DM, Minchin RF, Sim E. Changes in consensus arylamine $\mathrm{N}$-acetyltransferase gene nomenclature. Pharmacogenet Genomics. 2008;18(4):3678.

11. Zang Y, Doll MA, Zhao S, States JC, Hein DW. Functional characterization of single-nucleotide polymorphisms and haplotypes of human $\mathrm{N}$-acetyltransferase 2 . Carcinogenesis. 2007;28(8):1665-71.

12. Ayieko J, Abuogi L, Simchowitz B, Bukusi EA, Smith AH, Reingold A. Efficacy of isoniazid prophylactic therapy in prevention of tuberculosis in children: a meta-analysis. BMC Infect Dis. 2014;14:91.

13. Hein DW. N-acetyltransferase SNPs: emerging concepts serve as a paradigm for understanding complexities of personalized medicine. Expert Opin Drug Metab Toxicol. 2009;5(4):353-66.

14. Kurose K, Sugiyama E, Saito Y. Population differences in major functional polymorphisms of pharmacokinetics/ pharmacodynamics-related genes in Eastern Asians and Europeans: implications in the clinical trials for novel drug development. Drug Metab Pharmacokinet. 2012;27(1):954.

15. Cavaco I, Asimus S, Peyrard-Janvid M, Ferreira PE, Veiga MI, Hai TN, dkk. The Vietnamese Khin population harbors particular $\mathrm{N}$-acetyltransferase 2 allele frequencies. Clin Chem. 2007;53(11):1977-9. 